\title{
CAMPOS, RICARDO, \& CÂMARA, SÍLVIA (2020). ARTE(S) URBANA(S). VILA NOVA DE FAMALICÃO: HÚMUS
}

\section{Lígia Ferro}

Faculdade de Letras da Universidade do Porto, Departamento de Sociologia, Instituto de Sociologia da

Universidade do Porto. Via Panorâmica, s/n, 4150-564 Porto, Portugal. Email: lferro@letras.up.pt

O livro Arte(s) Urbana(s) publicado este ano pela Húmus com o apoio do CICS.NOVA Edições e da Fundação para a Ciência e a Tecnologia, foi escrito em parceria por dois profissionais das ciências sociais e humanas que trabalham, há mais de uma década, sobre a temática do graffiti e da arte urbana nos domínios da investigação e da intervenção. O prefácio e o posfácio estiveram a cargo de dois artistas de reconhecido prestígio internacional, originários das cidades de Lisboa e do Porto: Alexandre Farto (VHILS) e Miguel Januário (MaisMenos).

Trata-se de uma obra de reflexão que versa sobre as origens do espaço público e da cidade enquanto coração da democracia, a partir de uma análise histórica e filosófica que considera complexas relações entre democracia, espaço público e expressão estética. O texto assume um caráter deliberadamente ensaístico, partindo de uma base histórica da própria conceção de arte pública, que abrange aqui um escopo muito amplo, quer do ponto de vista temporal e espacial, quer ainda dos modos de expressão artística e estilos de intervenção no espaço público.

O livro resulta de um conjunto de conhecimentos sólidos e robustos, acumulados ao longo das trajetórias dos autores, aqui articulados em formato de ensaio. As reflexões críticas não têm de resultar sempre de pesquisas concretas com recolha sistemática de dados, num período limitado de tempo, e esta publicação é uma prova disso. Trata-se de um texto de articulação teórica em registo livre, que bebe da experiência empírica em diversos contextos e estabelece pontes relevantes entre temas fundamentais da arte pública.

A obra proporciona um bom itinerário compilatório de referências teóricas provenientes das ciências sociais e humanas, com destaque para a História, a História da Arte, a Filosofia e a Estética, e também de projetos concretizados empiricamente. O leitor pode então ganhar conhecimentos pertinentes no campo, em particular sobre as técnicas artísticas, as formas de expressão estética e as políticas públicas neste domínio. São também desvendadas algumas pistas sobre as dinâmicas sociológicas e antropológicas que a(s) arte(s) urbana(s) encerram, com potencial de aprofundamento no futuro.

Os autores declaram que o seu objetivo é "dar a conhecer um pouco da literatura académica sobre a matéria, numa perspectiva ampla e multidisciplinar, consolidando aquele que é, ainda, um campo de estudos em construção" (p. 175). Pese 
embora o facto de se assumir um caráter não exaustivo de referenciação, a verdade é que o leitor acede a uma panóplia extensa de informação teórico-empírica. O grande contributo dos autores reside precisamente no facto de elencar estes dados, dando-os a conhecer a meros curiosos e leigos na matéria, mas também aos investigadores que queiram aceder a uma visão panorâmica do campo, permitindo-lhes exploração futura. O formato adequa-se bem ao público em geral, num importante esforço de transferência do conhecimento acumulado ao longo dos percursos profissionais dos autores. Este é, sem dúvida, um dos contributos de relevo da publicação.

O texto divide-se em duas partes. A primeira, intitulada "Artes na Cidade", condensa a reflexão teórica dos autores em torno de conceitos basilares, tais como espaço público, graffiti, pós-graffiti, street art e arte pública. No capítulo intitulado "Expressões estéticas informais na cidade contemporânea", inclui-se uma abordagem histórica breve sobre o graffiti, o muralismo, street art, pós-graffiti e arte urbana. O grau de informalidade associado às diferentes expressões em questão, varia bastante e sabemos que no caso do muralismo norte-americano, sempre houve um forte apoio institucional ao movimento, tanto por parte do setor privado, como do público (Sieber, Cordeiro \& Ferro, 2012). Mais uma linha que poderá coser trabalho futuro.

Na segunda parte, o leitor pode aceder a um conjunto de exemplos de referência existentes em distintas cidades do mundo, principalmente no que toca à iniciativa dos artistas e às políticas públicas implementadas à escala urbana. Quem procura saber mais sobre a arte urbana no contexto português, poderá também encontrar uma análise pormenorizada da estratégia empreendida na cidade de Lisboa, assim como uma compilação de alguns projetos e iniciativas implementados noutros pontos do país, embora sem caráter exaustivo, como os próprios autores salientam. Esta última parte suscita a curiosidade, nomeadamente sobre os projetos localizados não só na segunda maior área metropolitana do país, a do Porto, mas também em outras pequenas e médias cidades, que têm sido decisivos para a estruturação de um campo forte na arte urbana em Portugal. Com certeza que a inclusão das vozes dos atores, se apresentadas em excertos de entrevista, por exemplo, poderia enriquecer ainda mais o conteúdo partilhado no livro e proporcionar ao leitor o acesso direto aos discursos e representações sociais dos protagonistas.

Campos e Câmara fazem um notável esforço em torno da definição do termo arte(s) urbana(s). O conceito de urbano assume a partir das ciências sociais, em particular da sociologia e da antropologia urbanas, uma dimensão específica da contemporaneidade, associando-se a uma expansão sem precedentes dos aglomerados urbanos, da qual o caso da cidade de Chicago se tornou emblemático, 
originando uma reflexão intensa e encorajando um grande desenvolvimento desses campos disciplinares. A especificidade da realidade urbana e a sua pertinência enquanto forma da qual emanam as práticas artísticas na rua, e não como um mero referente de expressão das mesmas, poderiam levar-nos facilmente a caraterizar estes fenómenos como eminentemente contemporâneos, estabelecendo uma clara distinção face a outros modos de expressão caraterísticos de períodos históricos mais longínquos. Ainda assim, compreende-se o exercício de colocar em relação, diversas formas de expressão artística e cultural do ser humano no espaço público, pela preocupação historiográfica que tão bem exprimem os autores como intenção, de facto consumada no livro.

Destaca-se a vertente criativa, liminar e subversiva destas manifestações culturais e artísticas dotadas de um "carácter aparentemente indomável" (p. 16), sublinhando-se igualmente a perseguição ao graffiti e aos seus protagonistas em diferentes territórios urbanos. A dimensão aparente desta realidade tem sido descrita e analisada em várias publicações, centrando-se nos processos de legitimação do graffiti e da arte urbana e na sua inclusão no campo da arte (Bourdieu, 1996). O clássico debate em torno do binómio arte ou vandalismo é enformado pelas perspetivas científicas em marcha, interessando, para além das configurações estéticas de expressão, as práticas dos indivíduos e a pluralidade de visões em jogo sobre a definição dos conceitos na base do referido binómio. A complexidade destas dinâmicas poderá aprofundar-se a partir de casos de estudo da literatura.

A experiência no espaço urbano é interpretada à luz de uma perspetiva histórico-geográfica em que “Cravar uma marca no território é, então, não apenas uma manifestação de existência (individual ou colectiva), mas igualmente uma tomada de posse, uma forma de atribuir propriedade ao espaço" (p. 66). Quando olhamos para este fenómeno a partir das lentes sociológica e antropológica, percebemos que esta conceptualização compete com outras, como não poderia deixar de ser, uma vez que falamos de espaços disciplinares pluriparadigmáticos. Por outro lado, existe investigação que aponta para a noção de apropriação como um conceito mais etic do que emic. Surge então em destaque, uma busca pela visibilidade na cidade através da expressão estética e cultural no espaço público. Para alguns autores, mais importante do que analisar os alegados modos de apropriação do espaço, importa compreender a arte urbana enquanto forma de ativismo social de rua (Tripodi, 2009). Nesta linha de trabalho, torna-se imperativo analisar as ruas como lugares simbólicos e de sociabilidade, relacionadas subjetivamente no conjunto do mapa urbano. Quando alguém escreve na rua, estará a afirmar esta cidade também é minha, mais do que a dizer esta parede é minha.

Este livro poderá interessar simultaneamente a investigadores, a artistas e a curiosos. Nele vemos elencada informação que será sem dúvida uma mais-valia 
para futuras explorações. Para além de ter um grande potencial de interesse para artistas, historiadores da arte, arquitetos, urbanistas e geógrafos, poderá também ser muito útil para o trabalho de sociólogos, antropólogos e outros profissionais das ciências sociais e humanas. É, sem dúvida, uma obra que poderá ser lida por uma audiência alargada e que ultrapassa os muros da academia, resultado de um nobre esforço de colocar o conhecimento ao serviço da sociedade.

\section{Notas}

Por decisão pessoal, a autora do texto escreve segundo o novo acordo ortográfico.

\section{Referências}

Bourdieu, P. (1996). As regras da arte. Génese e estrutura do campo literário. Lisboa: Editorial Presença.

Sieber, T., Cordeiro, G., \& Ferro, L. (2012). The neighborhood strikes back. Community murals by youth in Boston's communities of color. City \& Society, 24(3), 263-280.

Tripodi, L. (2009). Towards a vertical urbanism. Space of exposure as a new paradigm for public space. In A. M. Brighenti (Ed.), The wall and the city (pp. 47-62). Trento: Professional Dreamers.

Data de submissão: 10/12/2020 | Data de aceitação: 21/12/2020 